\title{
Influence of Computer Literacy Skill and Online Searching On Undergraduates' Use of Academic Materials in Babcock University Library
}

\author{
${ }^{1}$ Darlina Chima Ogbuiyi, ${ }^{2}$ Sussan Udoaku Ogbuiyi, ${ }^{3}$ Chuks Daniel Oriogu \\ ${ }^{1,2,3}$ Department of Library, Archival and Information Studies University of Ibadan Babcock University \\ Illisan-Remo, Ogun State Lead City University, Ibadan
}

\begin{abstract}
The exponential growth of information resources on the Web have necessitate the need for computer literacy and online searching skills to enhance easy access to and use of academic materials in university libraries for more productivity. The study adopted a Survey research design. Questionnaire was used to collect data for the study, and descriptive statistical method was used in analyzing the data collected and simple random sampling techniques were used to administer the questionnaire. The findings revealed that $88 \%$ of the respondents are computer literate which they acquire mainly through formal computer and IT training programme and are proficient on the use of Microsoft word, PowerPoint and Excel. Also, the study shows that majority of the students don't use Boolean logic in search of academic materials online. And that low speed access, inadequate computer system in the library and fluctuation of Internet services are the major challenges. The study recommends that university libraries should provide proper training on online searching skill, efficient Internet service and adequate computer system in the library.
\end{abstract}

Keywords: Computer literacy skill, Online searching, Use of academic materials, Babcock University library, Nigeria

\section{Introduction}

Information and communication Technology (ICT) encompasses the effective use of equipment and programs to access, retrieve, convert, store, organize, manipulate and present data and information (Gay and Blades, 2005). The uses of ICT as an emerging tool in the provision of library and information service to academic community include the computer and Internet. These enable undergraduate students to access information resources in richly formatted text and pictures. Debbie (1997) asserts that the World Wide Web "is the universe of network accessible information, an embodiment of human knowledge". It is the most popular medium for sharing information across the globe. However, ICT provides university libraries with capabilities for the location of information, storage, retrieval and dissemination of information. It also enables undergraduate students to locate and have access to information stored in other computers around the world; with Internet search engines, information stored in different Web pages can be easily retrieved.

\section{Literature Review}

The present generations of students are being surrounded by high level of digital technology that motivates them to have a high level of confidence while searching for information on the Internet and electronic sources. Therefore, the ability and knowledge of computer skills will enable them use the online resources effectively. It was observed that undergraduate students are looking for a convenient, time saving and fast response as they move from physical collections to the digital library (Lukersiwicz, 2007).

In this Internet-dominated and information rich culture, computer literacy skills have been undervalued. There is a mass of user-created content and collaborative work embedded in the digital technology that aids students to achieve their academic relevance and pursuit. Ball (2007) observed that the ability to succeed is the ability to adapt, it is about embracing and leading change, and therefore in this ever changing environment, it is important to create an active, learning environment not only by maximizing space but also by ensuring it is sympathetic to the developing pedagogies and students expectation.

The increase use of computer and the level of online searching by students and academics alike is an important measure of technological development in an academic environment. Thus, the computer is an electronic device that accepts data, process data, store data and disseminates data as meaningful output. The American Heritage Science Dictionary (2002) further defines a computer as the machine that can be programmed to manipulate symbols.

Computer literacy, which is the ability to operate a computer system for performing personal and jobrelated tasks like using web browsers and search engines on the Internet to retrieve needed information and 
communicate with the others (Hagar and Asefeh, 2008). Computer literacy is the ability and knowledge to use the computer effectively. Therefore, computer literacy is a necessity in the modern education in the $21^{\text {st }}$ Century. However, Computer literacy skill is defined as technical skills and level of proficiency in the general computer knowledge, documents and documentation, online searching (databases and search engines), and communications.

Allison (2005) pointed that, those without basic computer skill have difficult time finding job and stay connected with the local and global society. It has already been demonstrated that the demand for computerrelated skills has moved from insignificant to critical for most academic library positions (Zhou 1996). The acquisition of computer and information technology skills presents universities with significant challenges (NCHE, 1997). Computer literacy skill problems continued to be identified throughout the 1990's (Blyth and Royle, 1993). The teaching of computer literacy to students is of increasing importance as the dramatic increase in the use of the computer has come to the point that it is used for a range of learning task which is now a basic learning skill, as much as taking notes and reading texts (Reid, 1997).

However, there a need to consider how these skills can be developed across the entire institution in a consistent and cost-effective manner (Ferren, 1993). This should be done in a way that motivates and empower students to use this skills in the most effective manner possible so that students prior experience can be effectively acknowledge and built upon ( Lee, Pliskin and Kahn, 1994).

According to Goldman et al (1997) computer usage has numerous benefits, as it primarily assists students learning. Chavaz (1997) opines that Internet usage can also impact positively on critical thinking, problem solving, prompt feedback and collaborative instruction. Therefore, University libraries should provide an enabling environment that will aid students' computer literacy competence and effective online searching which is a necessity for new age students. Therein, Seely and Dudley (2000) have rightly observed that:

Those technologies offer new ways of producing, distributing and consuming academic materials. As with so many other institutions, new technologies have caused universities to rethink not simply isolated features but their entire mission and how they go about it.

The ability to use computer to search and retrieve information effectively becomes an essential skills useful for the undergraduate student's future life as well as enabling the positive and successful use of the electronic resources in the University. Majid (1999) argues that "libraries must reach a position where acquisition of information skills is acknowledge as one key learning objectives for every students entering a university, so that no student leaves without fully equipped to cope with the information intensive world and the information society-as an end user".

The proliferation of information resources on the Web has created a new way of searching endless volume of information online by undergraduate students. Harkins and Brown (1980) define online searching as the process of interactively searching for and retrieving requested information via a computer from database that are online. It is also the necessary skill required by students to access information resources effectively in this Information Age. According to Aina (2004) one of the major products of convergence of computer and telecommunication technology is the online searching. This product has greatly improved the provision of library and information services to users. He further asserts that online searching is a direct communication between a user and a computer system in an interactive mode. Online services employ online systems technology to provide remote users with access to information organized in databases with greater flexibility, precision and speed, (International encyclopedia of information and library science, 1997). Search strategies in finding relevant information which demands very specific searching skills and techniques, learning how to choose the right search engine and practicing effective search methods, help minimize the irrelevant and offensive material that can turn up in a search. Hartley et al (1997) have categorized on-searching into four major areas. They are: External/proprietary search service, CD-ROM, locally stored database and videotext/teletext system. On-line searching enables a user who is interested in a particular topic to explore the database with the combination of different search terms that matches his interest of information needs.

The availability of Web based tools used during academic research process is changing the way students access and use information in the library. Dudley (2008) asserts that, tools such as virtual and digital libraries, Online Public Access Catalogue (OPAC), Online Electronic Text Resources, Online Research Databases are all providing great relief to students in their quest for academic relevance and excellence, as database give them opportunity to access diverse materials on their academic researches. However, for undergraduate students to effectively perform online searching, they require good searching skill to function effectively. Dutton (1990) said that these skills include a knowledge of the structure of the database and the instruction which must be input in to the computer by the searcher, as well as the understanding of the ways in which the instruction are linked with one another. The cognitive demands of developing search are very much greater and have been identified as causing difficulties for novice searchers who tends to relay only on one term rather than several co-linked terms (Harter and Cheng, 1996). It is based on this discourse that Nwokedi (2007) posited that lack of searching skill is skill hindering good use of the Internet. 
It is pertinent to note that ICT has created a new environment for learning, teaching and research in academic institutions; therein, it is expedient that students should embrace this new technology in order to become independent learners.

\section{Statement Of The Problem}

In Nigeria university libraries, computer and online resources are now the order of the day. In order to effectively use computer and online resources, it is necessary to understand the computer literacy and online searching skills of undergraduate students. Therefore, this study investigated influence of computer literacy skills and online searching on undergraduates' use of academic materials in Babcock University Library.

\section{Objectives Of The Study}

The main objective of this study is investigate the influence of computer literacy skills and online searching on undergraduates' use of academic materials in Babcock University Library. The specific objectives to the study are to:

(i) find out if the respondents are computer literate;

(ii) examine the ways the respondents acquire computer literacy skills;

(iii) determine the level of computer literacy skill of undergraduates students;

(iv) ascertain the online strategies used by undergraduate students;

(v) determine the challenges encountered by undergraduate students in the use of computer and online searching of academic materials.

\section{Methodology}

Survey research method was adopted for the study and structured questionnaire was used to collect data. A total of hundred (100) undergraduate students of Babcock University were sampled, out of which ninety six was completed for analysis using frequency counts, simple percentage, mean, standard deviation, to answer the research questions. Thus, Random sampling technique was used to administer the questionnaire.

\section{Findings}

Table 1: Distribution of the respondents by Level

\begin{tabular}{|l|l|l|}
\hline Level & Frequency & Percentage \\
\hline 100 level & 8 & 8.4 \\
200 level & 16 & 16.8 \\
300 level & 43 & 45.3 \\
400 level & 27 & 28.4 \\
500 level & 1 & 1.1 \\
Total & 95 & 100.0 \\
\hline
\end{tabular}

Table 1 above shows that $8(8.4 \%)$ of the respondents are in 100 level, $16(16.8 \%)$ were from 200 level, $43(45.3 \%)$ are in 300 level, 27(28.4\%) are in 400 level, while $1(1.1 \%)$ is in 500 level.

Table 2: Distribution of the respondents by Gender

\begin{tabular}{|l|l|l|}
\hline Gender & Frequency & Percentage \\
\hline Male & 42 & 44.2 \\
Female & 53 & 55.8 \\
Total & 95 & 100.0 \\
\hline
\end{tabular}

Table 2 above shows that $42(44.2 \%)$ of the respondents were males while their female counterparts were $53(55.8 \%)$

Table 3: Distribution of the respondents by Age

\begin{tabular}{|l|l|l|}
\hline Age & Frequency & Percentage \\
\hline Under 18 years & 16 & 16.8 \\
18-22 years & 63 & 66.3 \\
Above 23 years & 16 & 16.8 \\
Total & 95 & 100.0 \\
\hline
\end{tabular}

Table 3 above shows that $16(16.8 \%)$ of the respondents were below 18 years, 63(66.3\%) were aged 18-22 years, while $16(16.8 \%)$ were above 23 years.

Question One: Are the respondents computer Literate?

Table 4: Computer Literacy level of the respondents

\begin{tabular}{|l|l|l|}
\hline Are you computer literate? & Frequency & Percentage \\
\hline Yes & 88 & 92.6 \\
No & 7 & 7.4 \\
Total & 95 & 100.0 \\
\hline
\end{tabular}


Table above shows that $88(92.6 \%)$ of the respondents were computer literate while $7(7.4 \%)$ were not computer literate;

\section{Research Question 2: What are the ways the respondents acquire computer literacy skill?}

Table 5: Ways the respondents acquire computer literacy skill

\begin{tabular}{|l|l|l|l|}
\hline $\mathrm{S} \backslash \mathrm{N}$ & Items & No & Yes \\
\hline 1 & Formal computer\T programs & $44 \quad 46.3 \%$ & $51 \quad 53.7 \%$ \\
\hline 2 & Practical self teaching & $5456.8 \%$ & $41 \quad 43.2 \%$ \\
\hline 3 & Assisted by friends $\backslash$ colleagues & $6972.6 \%$ & $2627.4 \%$ \\
\hline 4 & Computer\T books & $8084.2 \%$ & $15 \quad 15.8 \%$ \\
\hline 5 & Learn by trial and error & $78 \quad 82.1 \%$ & $17 \quad 17.9 \%$ \\
\hline
\end{tabular}

The responses on the ways of the respondents acquire computer literacy skill are as shown below: Formal computer \T programs? 44(46.3\%) of the respondents indicated No while 51(53.7\%) indicated Yes; Practical self teaching? 54(56.8\%) of the respondents indicated No while 41(43.2\%) indicated Yes; Assisted by friends $\backslash$ colleagues? $69(72.6 \%)$ of the respondents indicated No while 26(27.4\%) indicated Yes; Computer $\backslash$ IT books? $80(84.2 \%)$ of the respondents indicated No while $15(15.8 \%)$ indicated Yes; Learn by trial and error? $78(82.1 \%)$ of the respondents indicated No while $17(17.9 \%)$ indicated Yes.

Research Question Three: What is the level of Computer Literacy Skill of Undergraduates Students?

Table 6: Level of computer literacy skill

\begin{tabular}{|l|l|lc|lc|}
\hline $\mathrm{S} \backslash \mathrm{N}$ & Items & Agree & \multicolumn{2}{l|}{ Disagree } \\
\hline 1 & I can use Microsoft word very well & 90 & $94.7 \%$ & 5 & $5.3 \%$ \\
\hline 2 & I can use Microsoft access very well & 42 & $44.2 \%$ & 53 & $55.8 \%$ \\
\hline 3 & I can use Microsoft power point very well & 71 & $74.7 \%$ & 24 & $25.3 \%$ \\
\hline 4 & I can use Microsoft excel very well & 75 & $78.9 \%$ & 20 & $21.1 \%$ \\
\hline 5 & I can use coral draw very well & 37 & $38.9 \%$ & 58 & $61.1 \%$ \\
\hline 6 & I can proficiently use computer to do my academic work very well & 83 & $87.4 \%$ & $12 \quad 12.6 \%$ \\
\hline
\end{tabular}

The responses on level of Computer Literacy Skill of undergraduates Students in the study are as shown in table 6, it was revealed that the respondents can effectively use Microsoft word 90(94.7\%); Microsoft excel 75(78.9\%); and Microsoft power point 71(74.7\%) very well and also can proficiently use computer to do their academic work very well.

Research Question Four: What are the online strategies used by undergraduate students;

Table 6: Online Strategies

\begin{tabular}{|l|l|l|l|l|l|l|}
\hline $\mathrm{S} \backslash \mathrm{N}$ & Items & SA & AG & D & Mean & SD \\
\hline 1 & I often use title to search for academic materials & 16 & 64 & 15 & 2.52 & .76 \\
& & $16.8 \%$ & $67.4 \%$ & $15.8 \%$ & \\
\hline 2 & I can combine keywords to search for academic materials & 21 & 61 & 13 & 2.51 & .73 \\
& online & $22.1 \%$ & $64.2 \%$ & $13.7 \%$ & \\
\hline 3 & I use subject to search for academic materials & 19 & 61 & 15 & 2.48 & .76 \\
& & $20.0 \%$ & $64.2 \%$ & $15.8 \%$ & \\
\hline 4 & $\begin{array}{l}\text { I can effectively use Boolean logic in search of academic } \\
\text { materials online }\end{array}$ & $\begin{array}{l}11 \\
11.6 \%\end{array}$ & $\begin{array}{l}24 \\
25.3 \%\end{array}$ & 60 & $63.2 \%$ & \\
\end{tabular}

Note: SA (Strongly Agree), A (Agree), D (Disagree)

The responses to the Online Strategies employed by the Undergraduate Students in the study are as shown above; I often use title to search for academic materials (mean $=2.52$ ) ranked highest in the mean score rating and was followed by I can combine keywords to search for academic materials online (mean $=2.51)$, I use subject to search for academic materials (mean $=2.48$ ) and lastly followed by I can effectively use Boolean logic in search of academic materials online (mean $=1.62$ ).

Research Question Five: What are the challenges encountered by undergraduate students on the use of Computer and Online Searching?

Table 7: Challenges encounter computer and online searching

\begin{tabular}{|c|c|c|c|c|c|c|}
\hline $\mathrm{S} \backslash \mathrm{N}$ & Items & Never & Somewhat & Yes & Mean & SD \\
\hline 1 & Low speed access & $1616.8 \%$ & $1111.6 \%$ & $6871.6 \%$ & 2.55 & .77 \\
\hline 2 & Inadequate computer system in the library & $1818.9 \%$ & $8.4 \%$ & $6972.6 \%$ & 2.54 & .80 \\
\hline 3 & Internet service fluctuation & $1414.7 \%$ & $18 \quad 18.9 \%$ & $6366.3 \%$ & 2.52 & .74 \\
\hline 4 & Erratic power supply & $2526.3 \%$ & $34 \quad 35.8 \%$ & $3637.9 \%$ & 2.12 & .80 \\
\hline 5 & Frequent breakdown of the system & $3132.6 \%$ & $30 \quad 31.6 \%$ & $3435.8 \%$ & 2.03 & .83 \\
\hline 6 & Downloading of PDF files takes time & $3840.0 \%$ & $35 \quad 36.8 \%$ & $2223.2 \%$ & 1.83 & .78 \\
\hline 7 & Poor information literacy skill & $4547.4 \%$ & $32 \quad 33.7 \%$ & $1818.9 \%$ & 1.72 & .77 \\
\hline 8 & Unaware of where to locate needed information & $4850.5 \%$ & $33 \quad 34.7 \%$ & $1414.7 \%$ & 1.64 & .73 \\
\hline
\end{tabular}


The responses on the challenges encountered in the use of computer and online searching are as shown above: Low speed access (mean $=2.55$ ) ranked highest in the mean score rating and was followed by Inadequate computer system in the library (mean $=2.54$ ), Internet service fluctuation (mean $=2.52$ ), Erratic power supply (mean $=2.12)$, Frequent breakdown of the system (mean $=2.03$ ), Downloading of PDF files takes time (mean $=1.83$ ), Poor information literacy skill (mean $=1.72$ ) and lastly followed by Unaware of where to locate needed information (mean $=1.64)$.

\section{Discussion}

The findings show that female students formed the majority of the respondents. This is against the study of Ford, Miller and Moss (2001) who found that female students intended to experience more difficulty in finding information online. The findings of the study show that most of the responding students are computer literate and that the acquired this experience through formal computer training/IT programme and practical self teaching. It was revealed that the respondents can effectively use Microsoft word, Microsoft excel, and Microsoft power point very well and also can proficiently use computer to do their academic work. The findings also revealed that majority of the students don't use Boolean logic in search of academic materials online. Jansen, et al (1998) generally recognizes this task as difficult because the inputs supplied by the users are generally insufficient for collecting suitable data. And that low speed access, inadequate computer system in the library and fluctuation of Internet services are the major challenges encountered on the use of computer and online searching of academic materials.

\section{Conclution And Recommendation}

The study focus on undergraduate students who use computer to perform online searching in order retrieve information resources in the library for research and other academic purposes. Thus, in order to develop effective online searching and proficient use of the computer; it is necessary for university libraries to develop students computer literacy skill and online searching strategy through the provision of information literacy in order to make them explore information resources in the $21 \mathrm{st}$ Century as independent learners. And also university libraries should make adequate provision of computer system and effective Internet services.

\section{References}

[1]. Aina, L.O. (2004) Library and Information Text for Africa. Ibadan: Third world information. P. 314

[2]. Allison, S. (2005) "Computer Skills Essential to Break Poverty Cycle". Youth Studies Australia.Availableat:http://pdfserve.galegroup.com/pdfserve/get_item/1/S295120 w6_1/SB744_01.pdf. Retrieved February $6^{\text {th }}$, 2014

[3]. Ball, D.B. and Newland, B. (2007) Innovative e-learning with e-resources. Online information. proceedings. 121-126

[4]. Blyth, J. and Royal, J. A (1993) Assessing Nurses Information Needs in the Work Environments. Bull Medical Library Association, 81 (4): 433-435

[5]. Chavez, C. (1997) "Students take Flight with Daedalus: Learning Spannish in a Networked Classroom". Foreign Language Annals, 30(1):27-37

[6]. Debbie, A. (1997)“The Evolving Roles of Information Professionals in the Digital Age."Available at: http://www/mc.Maricopa.edu/its/lib/instructs/elib/mam2html. Retrieved on 23rd January, 2014

[7]. Ferren, A. S. (1993) General Education Reform and the Computer Revolution. The Journal of General Education, 42 (3): 164-177

[8]. Ford, N.,Miller,D., and Moss, N. (2001) The role of individual difference in Internet searching: An empirical study. Journal of American Society for Library and Information Science Technology. 52.(12): 1049-1066.

[9]. Gay, G. and Blades, R. (2005) Information Technology for CXC CSEC. Oxford University Press. Oxford, UK.

[10]. Goldman, S; Cole, K. and Syer, C. (1999) “The Technology/content Dilemma” Paper presented at the Secretary's Conference on \begin{tabular}{lllll} 
Educational Technology. & Retreved & on & $9^{\text {th }}$ & February, \\
\hline
\end{tabular} http://www.edu.gov/technology/techconf/1999/whitepaper/paper4.html

[11]. Hajar, S. and Asefeh, A. (2008) Computer Literacy Skill of Librarians: A case study of Isfahan University Libraries, Iran. ICOLIS. Pp..51-58

[12]. Harkins, D. T. and Brown, C. P. (1980) What is an Online Search? Online, 4 (1): 12-18

[13]. Hartley, R.J. et al (1990) Online Searching: Principles and Practice. London: Bowker Saur, p.387; In Aina, L.O. (2004) Library and Information Text for Africa. Ibadan: Third world information. p.314

[14]. Jansen, B., Spink, A., Bateman, J., and Saracevic, T. (1998) "Real life information retrieval: A study of users queries on the web." ACM SIGIR Forum, 32 (1):5-17

[15]. Lee, D. M. S. ; Plisein, N. and Kahn, B. (1994) The Relationship between Performance in Computer Literacy course and Students prior achievement and knowledge. Journal of Educational Computing Research, 10 (1): 63-77

[16]. Lukasiewicz, A. (2007) Exploring the Role of Digital Academic Libraries. Library Review, 56( 9): 821-827

[17]. Majid, S. and Abazora, A.F. (1999) "Computer Literacy and Use of Electronic Information Sources by Academics: A case study of International Islamic University Malaysia” Asia libraries. 8(8):100-111

[18]. National Committee of Enquiry into Higher Education (1997) Higher Education in the Learning Society. Available at: http://www.leeds.ac.uk/educol/ncihe. Retrieved on 30th January, 2014

[19]. Nwokedi V. C. (2007) Impact of Internet use on teaching and research activities of the academic staff of faculty of medical sciences, University of Jos: A case study. Gateway Library Journal, 10(1): 13-22.

[20]. Reid, I (1997) Computer literacy in higher education. Ascilite. Available at : http://www.ascilite.org.au/conference/perth97/papers/Reid/Reid.html. Retrieved January $25^{\text {th }}, 2014$.

[21]. Seely, B. J. and Duguid, P. (2000) The social life of information. Harvard Business School Press. Boston, MA.

[22]. Zhou, Y. (1996) "Analysis of trends for computer-related skills for academic librarians from 1974 to1994", College and Research Libraries, 259-271pp. 